\title{
HISTORIA HISTORIOGRAFII: KSIAZŻKA TELEFONICZNA, CZY FRAGMENT SOCJOLOGII WIEDZY?
}

Marcin KULA

\section{ABSTRACT}

HISTORY OF HISTORIOGRAPHY: A PHONE BOOK OR A FRAGMENT OF THE SOCIOLOGY OF KNOWLEDGE?

In this article the author argues for the rapprochement between the methods and questions of the history of historiography and the questionnaire of the sociology of knowledge. The sociological perspective can inspire both the research on the communities of professional historians and the functioning of the historiographical knowledge in social and political structures. The author analyzes different dimensions of the political functions of historiography and emphasizes the difference between the utilitarian and scientific aspects of historical knowledge.

\section{KEYWORDS:}

History of historiography, sociology of knowledge, politics of history, contemporary history 
Nie jestem historykiem historiografii. Proszę przyjąć poniższą wypowiedź jako swego rodzaju zapotrzebowanie, zgłoszone przez człowieka z zewnątrz, czego chciałbym się dowiadywać od kolegów z owej branży. Czasem taka zewnętrzna wypowiedź nadaje się do zdezawuowania, jako zawierająca „odkrycia” dyletanta. Czasem jednak zawiera myśli świeże, bowiem sformułowane bez obciążenia dotychczasowym stylem uprawiania danego ogródka. Nie mnie oceniać co jest wart mój głos . Nie dezawuujcie go jednak, Koledzy, jedynie w samoobronie. Nie atakuję Was. Pamiętajcie też, że to wyście zaprosili mnie na spotkanie.

Prawda jest taka, że - według stanu na dzień dzisiejszy - już od dawna nie oczekuję wiele ciekawego od historii historiografii. Może zbyt mało wiem o tym, co się w tej dyscyplinie tworzy, może jestem wciąż naznaczony okresem studiów, kiedy były to doprawdy najmniej ciekawe zajęcia, może... Tak, czytałem ciekawe rzeczy Krzysztofa Brzechczyna, Macieja Bugajewskiego, Ewy Domańskiej, Wojciecha Piaska, Zbigniewa Romka, Rafała Stobieckiego, Joanny Wojdon, Wojciecha Wrzoska ... pewno jeszcze innych Koleżanek i Kolegów, których nazwiska akurat uciekły mi z pamięci. Wielu dyscyplinom jest jednak bardzo trudno wyzwolić się z grzechu pierworodnego. Niekiedy odnoszę wrażenie, że nad historią historiografii - niezależnie od występujących w niej rodzynek - wciąż ciąży wzór książki telefonicznej, na dodatek spisanej przez pozytywistę. Nad innymi dyscyplinami historycznymi często zresztą też.

Czego chciałbym od historii historiografii, nakierowany zresztą w moich chęciach także ciekawymi wynikami wymienionych autorów? Chciałbym, po pierwsze, zajęcia się możliwie jak najszerszą panoramą form wypowiedzi o dziejach, a nie tylko tomami pisanymi nawzajem dla siebie przez gabinetowych historyków. Od najdawniejszych czasów, zapewne we wszystkich cywilizacjach, owe formy były zróżnicowane. Egipskie piramidy i afrykańscy grioci na swój sposób wyrażały/ wypowiadali myśli o historii. W naszych czasach choćby środki wizualne, z sukcesem badane przez Dorotę Skotarczak i Piotra Witka, często zawierają treści historyczne nie mniej istotne, a z pewnością szerzej rozpowszechniające się niż wypowiedzi zawodowych historyków'. Teatr jest znaczącym forum wypowiedzi o historii - zarówno w wersji budującej chwałę przeszłych pokoleń, jak w warstwie krytycznej analizy ich dokonań ${ }^{2}$ Dziś także muzea,

1 D. Skotarczak, Historia wizualna, Poznań 2012 (II wyd. 2013); P. Witek, Andrzej Wajda jako historyk. Metodologiczne studium z historii wizualnej, Lublin 2016. Por.: E. Domańska, Historie niekonwencjonalne: refleksja o przeszłości w nowej humanistyce, Poznań 2006.

2 Z niedawnych realizacji por. dwie sztuki Teatru Pijana Sypialnia w Warszawie: „Latarnik” (scenariusz S. Narloch, reż. S. Dembski, premiera 15 maja 2016 r.) i „Wesele” (scenariusz i reż. S. Narloch, premiera 17 września 2016 r.). W obydwu spektaklach wykorzystano klasyczne teksty, by je przetworzyć w krytyczną wypowiedź o narodowych mitach. 
podręczniki, reportaże historyczne, rekonstrukcje historyczne ${ }^{3}$, gry komputerowe i planszowe, gry karciane, powieści historyczne, publicystyka, komiksy, architektura (zarówno w warstwie odbudowy dawnych budynków, jak nawiązywania bądź zrywania ze stylem dawniejszej sztuki) powinny wejść w zakres historii historiografii. Gdy Aleksander Gieysztor odbudowywał Zamek Królewski w Warszawie, wypowiadał się o historii. Robił to nawet w konkretnych założeniach projektu odbudowy („Nawiązanie do składni symbolicznej Zamku stanisławowskiego i po roku 1918, w obecnej odbudowie znajduje swój głęboki sens w programie Stanisława Augusta, który z umysłu stosował wielka dydaktykę patriotyczną i przesycił nią tworzone według jego wskazówek wnętrza”4). Myśli o historii warte analizy zawarte są także w pomnikach, rzeźbach, obrazach i dekoracjach różnego typu ${ }^{5}$. Znakomitym przykładem takiej wypowiedzi o historii jest ciąg płaskorzeźb zrobionych przez Ryszarda Skupina (1966) w holu kolumnowym Zamku w Poznaniu, gdzie artysta przedstawił dzieje miasta i regionu ${ }^{6}$.

Działania polityczne, w ogóle cała polityka bywa wypowiedzią o dawnych i obecnych losach ludzkich. Wypowiada się w ten sposób nie tylko każdorazowy rząd w ramach oficjalnej „polityki historycznej”. To także wypowiedź na przykład społeczności miasteczka namiotowego, zorganizowanego w 2016 r. przed siedzibą Sądu Najwyższego w Warszawie. Na transparentach, plakatach i planszach można tam przeczytać opinie o PRL, o genezie III RP jako rzekomym przedłużeniu PRL, także teksty o kolejnych ludziach jako zanurzonych w PRL. Moim zdaniem wszystko to jest warte refleksji historyków historiografii.

W naszych czasach trzeba bowiem postawić pytanie o istnienie historiografii zawodowej, a w wypadku odpowiedzi pozytywnej o jej granice. Czy istnieje jeszcze coś takiego jak ustalone zawodowo kryterium prawdy w historiografii? Sam chciałbym, żeby historia zawodowa istniała i żebyśmy mogli przynajmniej w jej ramach porozumiewać się chociażby w kwestii tego, co jest fałszem (określenie prawdy jest bardziej skomplikowane). Granica zawodu jednak zaciera się, zaś bzdura bzdurę goni często i bez istotnych oporów. Trzeba, moim zdaniem, posypać głowę popiołem i przyznać się, że jako zawodowi historycy utraciliśmy prowadzenie w formulowaniu wizji historii

3 T. Szlendak, J. Nowiński, K. Olechnicki, A. Karwacki, W. J. Burszta, Dziedzictwo w akcji. Rekonstrukcje historyczne jako sposób uczestnictwa w kulturze, Kraków 2012.

4 Cyt. za: P. Mrozowski, A. Gieysztor i Zamek Królewski w Warszawie, w: Aleksander Gieysztor. Człowiek i dzieło, red. M. Koczerska, P. Węcowski, Warszawa 2016, s. 99.

5 Przykładowo: M. Praczyk, Materia pomnika. Studium porównawcze na przykładzie monumentów w Poznaniu i Strasburgu w XIX i XX wieku, Poznań 2015.

6 Dziękuję Kolegom pracującym w Centrum Kultury „Zamek” za zwrócenie mi uwagi na to dzieło. 
proponowanych społeczeństwu; nie jesteśmy już „przewodnikami stada”. We współczesnej „polityce historycznej”, niezależnie od tego w czyim wydaniu, historycy nie są już specjalnie potrzebni, a jeśli, to raczej jako wykonawcy. Podstawowe obrazy ustalają politycy - choć czasem będący historykami z wykształcenia.

Chciałbym, ażeby historia historiografii obejmowała formy refleksji nad możliwie jak najdłuższym okresem dziejów - nie tylko jak najwcześniej zaczynanym, ale też jak najpóźniej kończonym (po prostu kończonym dziś!). Nie widzę fundamentalnej różnicy w dziejach pomiędzy „dziś” a „wczoraj” - chyba, że dziś, z grubsza o północy, zajdą jakieś specyficzne okoliczności, nie wynikające jednak już tylko z kalendarza. Nadto warto pamiętać, że współczesność bardzo szybko staje się przeszłością, zaś przeszłość oddziałuje bezpośrednio oraz bywa polem odwołań. Luźnym skojarzeniem: pojawia się w opracowaniach i wspomnieniach, że gdy prymas Wyszyński zapowiedział ks. Wojtyle, że zostanie biskupem, ten miał zapytać, czy nie jest za młody. Na to prymas miał podobno powiedzieć, że z tej wady szybko się leczymy.

Nie akceptuję stanowiska naszych nauczycieli, że XX w. nie jest już domeną historyków. Położenie ciężaru studiów historycznych na epokach dawniejszych wydaje mi się dziś nieżyciowe. Zamiast chronologicznego tłuczenia ich, położyłbym też raczej nacisk na to, co wnosiły one do naszej kultury, co z nich widać w dzisiejszym świecie, a co zostało odrzucone i dlaczego. To samo dotyczy historii historiografii.

Chciałbym, ażeby historiografia obejmowała jak najszersze pola geograficzne a od historii historiografii oczekiwałbym analizy w jakim stopniu widziano odległe tereny oraz czy patrzano na nie tylko w kontekście kontaktów białego człowieka $\mathrm{z}$ „tubylcami”. Rozpoczynanie analizy dziejów dowolnego lądu od stwierdzenia, że ów ląd został „odkryty” w roku x, nie ma sensu. Jego mieszkańcy sami nie musieli się odkrywać. Od historii historiografii pragnąłbym też odpowiedzi na pytanie, czy poznanie odległych terenów i ludów jakkolwiek wpłynęło na widzenie własnej przeszłości przez historyków europejskich oraz, z drugiej strony, w jaki sposób nasze szkoły badawcze naznaczyły tamtejsze. Pytanie, w czym tamtejsi historycy szukali tego, co z ich punktu widzenia było swoje, jest ważnym pytaniem.

Chciałbym, ażeby historia historiografii stawiała pytanie o przedstawianie różnych dziedzin życia. Z pola historiografii wypączkowały różne subdyscypliny, które często mocno się rozdzieliły, a bywają uprawiane przez przedstawicieli zupełnie innych dziedzin (historia architektury, literatury, medycyny, sztuki ...). Otóż musimy przyjąć do wiadomości, choć jest to trudne, że człowiek jest jednością. Jednością jest także życie indywidualne oraz społeczne. Historia historiografii winna zatem zwracać uwagę 
na to jak byly oraz jak są zarysowywane - przez historyków oraz przez naszych kolegów - dziedziny, które, choć specyficzne, stanowiły i stanowią jednak część dziejów.

Historia historiografii winna stawiać pytanie o to, co nie pojawia się w dziejopisarstwie. Trudno oczywiście wytykać luki Długoszowi bądź krytykować naszych przodków za brak postępowania zgodnie z dzisiejszymi zainteresowaniami i regułami. Czym innym jest jednak krytykowanie od próby odpowiedzi na pytanie jakie sprawy, dziś nas interesujące, $\mathrm{z}$ ich punktu widzenia były na tyle nieważne lub banalne, że ich nie zauważali. Postawienie takiego pytania byłoby zresztą warte grzechu także w odniesieniu do historiografii współczesnej - jeżeli ktoś potrafiłby sobie zdać sprawę obok jakich ważnych spraw przechodzimy bezwiednie i w konsekwencji także o nich nie piszemy.

W ramach rozważanej dyscypliny zapytałbym jak miał się przedmiot historiografii do tego, czym w swojej epoce, wręcz w swoim własnym życiu, interesowali się historycy (też ludzie!). Upadek komunizmu zwiększył zainteresowanie tym ustrojem oraz procesami, które doprowadzily z jednej strony do jego zapanowania, a z drugiej do jego upadku. Dziś nabranie wagi przez problem gejów bądź zagadnienia feministyczne ma wpływ na zainteresowania historyków historią kobiet oraz mniejszości. Co jednak sprawiło, że pojawiło się zainteresowanie się dziejami życia codziennego? Czy szybkość jego zmian unaoczniła wagę sprawy? Dekolonizacja, a zwłaszcza emancypacja Afryki, zwróciła uwagę na historię tego kontynentu, Rewolucja Kubańska na dzieje Ameryki Łacińskiej... Czy zawsze mechanizm wzbudzenia zainteresowania historiografii był jednak taki sam? W Stanach Zjednoczonych współczesny renesans sprawy indiańskiej wzmocnił zainteresowanie nią ze strony historyków. Problem nie jest jednak przecież nowy, zaś dawniej historycy - jeśli się nie mylę - nie poświęcali mu nadzwyczajnej uwagi (jeśli nawet poświęcali, to na pewno z innego niż dziś punktu widzenia).

Postawiłbym pytanie jak ewoluował i jak będzie ewoluować do niedawna klasyczny rodzaj historiografii, dziś wciąż popierany przez część kolegów i znaczącą część czytelników - czyli uprawianie historii narodowej. W obliczu współczesnych zmian wielu państw, uznania ich wieloetniczności, uznania prawa do pamięci grup mniejszościowych bądź społecznie słabszych, także cywilizacyjnego zmniejszania się świata oraz kształtowania całości cywilizacyjnych wielkich rozmiarów, koncept historii narodowej musi ewoluować.

Zadałbym pytanie czy historycy będą zajmować się, jak w przeważającej mierze dotychczas, ciągiem chronologiczno-skutkowym - i to w ramach jednego narodu/ państwa - czy też może zjawiskami, które trzeba badać w możliwie różnych miejscach występowania oraz w różnych epokach (przy pamiętaniu o zmienności dziejowej!). 
Z góry powiem, że aczkolwiek historię chronologiczno-faktograficzną uważam za istotną, to jednak żałuję braku powszechniejszego uprawiania socjologii historycznej, którą staram się promować. Mam wrażenie, że jako historycy oddajemy kolegom-socjologom ogromne pola. Tymczasem można je uprawiać wspólnie.

Oczekiwałbym od historii historiografii nie tylko stwierdzeń, że liczący się twórcy byli pracowici i przerobili wszystkie źródła. Takie komplementy pod adresem historyków mnie śmieszą. Z samej pracowitości jeszcze nie musi wynikać wiele dobrego, a jeśli wynikają rzeczy dobre, to raczej rzemieślnicze. Chciałbym otrzymywać od Was, Koleżanki i Koledzy, informację o zapleczu intelektualnym twórców, którymi się zajmujecie, a zwłaszcza o ich możliwościach. IQ było tylko jedną z ich przesłanek. Chciałbym się dowiedzieć o wykształceniu tych ludzi, zaproponowanej im podczas studiów formule historiografii oraz ich ewentualnym buncie wobec niej, także o ich światopoglądzie, aktywności pozazawodowej, zdolności zewnętrznego spojrzenia na własne społeczeństwo. O ile jestem dobrze zorientowany, w programie studiów historycznych w niewielkim stopniu pokazuje się ewolucję naszych metod. Pokazuje się historiografię jako nieustająco pozytywistyczną (należy dużo siedzieć, możliwie wszystko przeczytać, skonfrontować źródła ... no i napisać możliwie najpełniejszy tekst). Znacznie mniejszą wagę przywiązuje się do pokazywania potrzeby myślenia koncepcyjnego. Gdyby historiografia miała być tak nieewolucyjna, jak często wynika $\mathrm{z}$ treści przekazywanych studentom $\mathrm{w}$ tej kwestii, to biada nam. Nawiasem mówiąc, zalecenie przerobienia możliwie wszystkich źródeł jest w odniesieniu do dziejów najnowszych całkowicie nierealistyczne.

Oczekiwałbym od historii historiografii refleksji jaki wpływ miała na historyków praca akurat $\mathrm{w}$ danym kraju, może także praca nad wybranym krajem - co nie musi się przecież pokrywać. Ta sprawa zaczyna się od wyboru tematyki. W końcu, dla oczywistych przyczyn, istnieje duża szansa, że historyk holenderski lub historyk Holandii weźmie pod uwagę związek człowieka z gospodarką wodną, historyk chiński zajmie się produkcją ryżu i wszystkim, co ona pociągnęła w zakresie rozwiązań społecznych, historyk irlandzki - głodami oraz emigracją, zaś historyk islandzki - rybami. Sprawa jest jednak głębsza. Historiografia i socjologia tradycyjnie są w USA bliżej siebie niż w wielu krajach, gdyż obie te dyscypliny obserwowały kraj w procesie tworzenia się, gdzie przenikały się zjawiska stanowiące zwyczajowe pole zainteresowań obu dyscyplin ${ }^{7}$. Także w innych krajach uwarunkowania zainteresowań i metod pracy historyków mogły i mogą być głębokie.

7 Ł. P. Wojakowski, Państwo i zmiana społeczna w teoriach amerykańskiej socjologii historycznej, Kraków 2011 (rec.: M. Kula, Dzieje jako materiat dla socjologów, Kultura i Społeczeństwo, 2011, nr 4, s. 288-291). 
Chciałbym widzieć w jakim stopniu jesteśmy jako historycy uwarunkowani przez epokę, w której żyjemy i przez drogi myślenia właściwe dla naszego środowiska. Wiadomo, że nurty myślenia, które nas poprzedziły, warunkują nasze myślenie dziś. Może jednak i one, i nasze dzisiejsze myślenie, warunkują też nasze myślenie o przeszłości? To się czasem nie da rozdzielić. Hitleryzm nie wyrósł na intelektualnym surowym korzeniu, nawet jeśli na niektórych polach dopiero on przekroczył zbrodnicza granicę, bądź uczynił to na skalę przedtem niespotykaną. Sam Thomas Mann w maju 1919 r. zalecał, aby „ów typ rosyjskiego Żyda, przywódcy światowego ruchu, ową wybuchową mieszankę żydowskiego radykalizmu intelektualnego i słowiańskich fantazji o Chrystusie” potraktować jak najostrzej ${ }^{8}$. Takie myślenie musiało rzutować zarówno na analizy teraźniejszości, jak przeszłości.

Chciałbym pokazywania przez historię historiografii w jakim stopniu nasi zawodowi przodkowie byli (a także w jakim stopniu my jesteśmy) zależni od społeczeństwa, w tym również, węziej, od rządzących elit, a w jakim szli własnymi drogami. Sprawa jest trudna. W końcu historycy pracują nie tylko dla siebie. Sami jesteśmy w jakimś stopniu odbiciem społeczeństwa, a niektórzy z nas wręcz chcą nim być. Co nie najmniej ważne, społeczeństwo nas tak, czy inaczej, finansuje (szkoda, że nie lepiej!). Niektóre formy dziejopisarstwa, jak twórczość filmowa i muzea, są na tyle kosztowne, że ich twórca nie może sobie powiedzieć: a tam, ja mam własny obraz historii, najwyżej napiszę książkę do szuflady. W tej sytuacji odwrócenie się od wymogów stawianych przez społeczeństwo byłoby nierealistyczne. Daleko jednak od tego do poddania się zdaniu wicepremiera Piotra Glińskiego, sformułowanego we wrześniu 2016 r., gdy wypowiadał się przeciw koncepcji Muzeum II Wojny Światowej w Gdańsku. Odnosząc się do założeń Muzeum, powiedział on: „W tej koncepcji musi być wyrażone także w większym czy głębszym sensie tego słowa stanowisko tych polityków, którzy obecnie mają mandat społeczny dotyczący polityki historycznej”’

Odpuśćmy sobie w tym miejscu dyskusję kwestii kto na co ma mandat. Nie wątpię, że koncepcja dziejów wicepremiera Glińskiego oraz jego działania w odniesieniu do ich przedstawienia są bliższe przeciętnym narodowym uczuciom niż moje myśli. Pytanie tylko, w jakim stopniu historyk winien się podporządkowywać społeczeństwu, a w jakim iść drogą, którą uważa za wynikającą z jego badań i refleksji? Oczywiście, nie zawsze musi być ona rozbieżna z myśleniem najczęstszym w społeczeństwie. Ci, którzy w PRL pracowali na rzecz zapełnienia „,białych plam”, wchodzili w konflikt z władzami,

8 A. Rosenberg, Dzienniki 1934-1944, red. i komentarz J. Matthäus, F. Bajohr, tłum. M. Antkowiak, Warszawa 2016, s. 40 .

9 Polityka, nr 39, 21-27 IX 2016. 
a nie z większością społeczeństwa. Może jednak zdarzyć się zupełnie inaczej. Jak zaś bywało w historii dziejopisarstwa powinna pokazać historia historiografii.

Ciekawym zagadnieniem dla historii historiografii są kontakty historyków różnych krajów (lub ich brak) oraz wzajemne wpływy (lub ich brak). Problem odnosi się do różnych epok, ale w odniesieniu do niedawnych i do epoki współczesnej jest szczególnie znaczący ze względu na „zmniejszenie się” świata. Historycy polscy już za głębokiej PRL mieli żywe kontakty z kolegami francuskimi, potem z niemieckimi. Trudnym pytaniem jest, czy wykorzystywali te pobyty jedynie dla lektury źródeł i opracowań, czy też dawał się zaobserwować wpływ francuskiej lub niemieckiej metodologii w polskiej historiografii ? $^{10}$. Historiografia wielu krajów Ameryki Łacińskiej zmieniła się radykalnie pod wpływem kontaktów zagranicznych w latach sześćdziesiątych; pytanie, czy nasza także?

Oczekiwałbym od historii historiografii położenia nacisku na analizę schematów myślenia historyków, których często sami, jako badacze, sobie nie uświadamiamy. Co historycy uważają za wyjaśnienie zjawisk (wydarzeń), o jakich piszą? Jakie przyjmują przesłanki opisywanego działania ludzi? Jakie zakładają głębsze mechanizmy wydarzeń? Odnoszę wrażenie, że najczęściej działamy zdroworozsądkowo, bez uwzględnienia dorobku innych nauk o człowieku, nieraz wręcz naiwnie („było im źle, więc się buntowali”, „wszyscy byli przeciw”, „ożywieni patriotyzmem walczyli”... ). Dodatkowym aspektem zagadnienia jest uleganie schematom myślenia popularnym w społeczeństwie, którego jesteśmy częścią. Jakże często powinniśmy w ich kontekście powiedzieć „tak, ale ...”zaś nie zawsze mówimy. Prawda, że zdarza się wśród nas postawa godna historyka. Stworzenie Muzeum II Wojny Światowej i obrona jego koncepcji przez liczne grono historyków jest tu dobrym przykładem. Jan Pospieszalski najpewniej odzwierciedla szeroko rozpowszechnione zapotrzebowanie na zaspokojenie przez dyskurs historyczny pewnych funkcji, gdy mówi: „Proponowany kształt tej wystawy nie gwarantuje pokazania prawdy o tragizmie i wyjątkowości polskiego losu w tym czasie. Rozmywa to unikalne doświadczenie polskie w całym szeregu nieporównywalnych wydarzeń. Polacy zasługują na lepsze muzeum, na prawdziwą opowieść o dzielnym narodzie, który dzięki zakorzenieniu w wartościach chrześcijańskich najpierw przeciwstawił się dwóm totalitaryzmom, a potem mimo wszystko zdołał przejść przez niewyobrażalną gehennę" . Cieszę się wszakże, iż twórcy Muzeum i historycy ich popierający pamiętają, że obowiązkiem historyka jest analiza rzeczywistości, a nie kierowanie się

10 Por.: P. Pleskot, Intelektualni sąsiedzi. Kontakty historyków polskich ze środowiskiem Annales. 1945-1989, Warszawa 2010, s. 683-741.

11 Przeżyli szok bo naród się zbuntowat (Jacek i Michał Karnowscy rozmawiają z Janem Pospieszalskim), wSieci, nr 37, 5 IX 2016. 
potoczną wizją. Jestem wprost dumny, że twórcą krytykowanej koncepcji Muzeum jest mój uczeń, prof. Paweł Machcewicz.

Obrona społeczeństwa przed zmianą wizji historii na mniej je waloryzującą może iść daleko. Charakterystyczne, że zarówno we Francji, jak w Niemczech, jak w Polsce, dużą rolę w procesie zmiany odegrali historycy zagraniczni - jak gdyby krajowi byli zbyt nieśmiali, przynajmniej do zapoczątkowania procesu. O ile wiem, we Francji i w Niemczech nie wzywano jednak nikogo z owych inicjatorów do prokuratury, jak w Polsce Jana Tomasza Grossa. Formą obrony jest też rozszerzanie zagrożenia głoszenia pewnych treści historycznych penalizacją. Karanie za „obrazę narodu" jest klasycznym działaniem w imię obrony miłości własnej (w odróżnieniu od karania „kłamstwa oświęcimskiego”, co też nie wzbudza mojego entuzjazmu, ale karze działanie uwłaczające pamięci ofiar).

Wyjątkowym casusem wykorzystywania historiografii przez społeczeństwo reprezentowane przez system polityczny bądź zniewolone przez system polityczny (rozróżnienie to, wbrew pozorom, niekoniecznie jest ostre) bywa instrumentalne wykorzystywanie jej w ustrojach niedemokratycznych. Przecież zarówno Stalin, jak Hitler byli fascynatami historii własnych krajów - czego nominalny internacjonalizm Stalina nie powinien przesłaniać. Wojnę z Hitlerem Stalin nazwal „ojczyźnianą” - przez nawiązanie do walki z Napoleonem. W schronie w Kujbyszewie, skąd miał dowodzić w wypadku oddania Moskwy, zawieszono na ścianach portrety najwybitniejszych wodzów rosyjskich. Hitler nawet w swoich rozmowach co chwila nawiązywał do historii, zwłaszcza do Fryderyka Wielkiego ${ }^{12}$. Jako ośrodki szkoleniowe NSDAP hitlerowcy tworzyli „twierdze zakonne” - pewno na wzór Krzyżaków. Jedną z nich chcieli nawet umieścić obok Malborka, ale uznali, że dwie twierdze obok siebie to za dużo. Doczesne szczątki Fryderyka zabezpieczyli przed bombardowaniami pewno jeszcze lepiej niż mityczny „złoty pociąg” - choć akurat te zwłoki odnaleziono. W naszych czasach Hugo Chávez, prezydent Wenezueli w latach 1999-2013, ogromną część swego dyskursu zorganizował wokół historii. Zdecydował nawet o odkopaniu grobu Bolivara. Był przy tym obecny i jakoby poczul „ogień”, bijący od szlachetnych szczątków.

Socjologowie interesują się pamięcią historyczną. My zaś powinniśmy zainteresować się funkcjonowaniem tej pamięci w działaniu i odwołaniami do historii (nota-bene: pamięć, pamięć wykorzystywana używana, odwołania i pamięć zsymbolizowana to nie to samo!). Także miejscem historyków w tym wszystkim - jako przedmiotów i jako podmiotów. Takie i podobne zjawiska przenikały i przenikają bowiem historiografię poszczególnych krajów. Historiografia bywa też po prostu

12 A. Rosenberg, dz. cyt., passim. 
służebna. Skądinąd kwestii systemów politycznych dotyczy interesujące dla historii historiografii zagadnienie tworzenia, zachowywania oraz dostępności źródeł i typu wytwarzanych, także wykorzystywanych źródeł.

„Historia a polityka” (i odwrotnie) to wielkie zagadnienie ${ }^{13} .24$ września 2016 w warszawskim marszu KOD-u niesiono m.in. hasło „Historia jest bezpartyjna”. Na taki postulat pada czasem uwaga, że jakaś „polityka historyczna” zawsze występuje, jak zawsze jest jakaś pogoda. Oczywiście, my sami, będąc historykami, rzadko potrafimy być neutralni bez reszty. Jako ludzie reprezentujemy pewne systemy wartości. Jako historycy nieraz uczestniczymy w różnych ruchach społecznych. Często myślimy wtedy o historii, jej drogach i jej mechanizmach - nawet jeśli twierdzimy, że badania zostawiliśmy w domu. Część z nas uczestniczy w życiu Kościoła (Kościołów), a one są nośnikami treści historycznych z natury religii oraz dlatego, że zarówno instytucjom, jak poszczególnym świątyniom, ludzie powierzali w dziejach pewne treści historyczne dla ich przetrwania (na przykład w postaci tablic wmurowywanych w ściany świątynne, także takich tablic, których nie można było umieścić gdzie indziej). Warto zauważyć jednak różnicę pomiędzy tym, że jesteśmy „tylko” ludźmi i nie potrafimy być całkowicie neutralni, a świadomą i celową polityką partii rządzącej oraz państwa - niezależnie od tego w jakim kierunku prowadzącej.

Niekiedy dążenie do rewolucyjnego przetworzenia wizji historii jest związane z rewolucyjną zmianą społeczeństwa - czasem szczęśliwą, czasem nie. Podobnie przetworzenie wizji bywa czasem szczęśliwe, a czasem nie - ale zawsze interesujące dla historii historiografii. Jako historycy zawsze dostarczamy materiału do badania dla Kolegów ją uprawiających - nawet jeśli czasem mądrego, a czasem głupiego.

Chętnie widziałbym zajęcie się przez Koleżanki i Kolegów funkcjami historiografii w społeczeństwie. Jest oczywiste, że treści historyczne były, są i zapewne będą argumentami w różnych sprawach, punktami odniesienia, identyfikacją korzeni i znakiem tożsamości grup, lepiszczem społeczeństwa oraz instrumentem dowartościowania

$13 \mathrm{Z}$ niedawno publikowanych źródeł por. przykładowo: S. Kieniewicz - Henryk Wereszycki. Korespondencja z lat 1947- 1990, red. E. Orman, Kraków 2013. Z opracowań przykładowo: P. Hübner, Polityka naukowa w Polsce w latach 1944-1953. Geneza systemu, t. I-II, Wrocław 1992; Tenże, I Kongres Nauki Polskiej jako forma realizacji zatożeń polityki naukowej państwa ludowego, Wrocław 1983; Z. Romek, Historycy radzieccy o historykach polskich. Uwagi o Zjeździe Wrocławskim (1948) i konferencji otwockiej (1951/52), Polska 1944/45 - 1989. Studia i Materiaty, t. IV, 1999; T. Paweł Rutkowski, Nauki historyczne w Polsce 1944- 1970. Zagadnienia polityczne i organizacyjne, Warszawa 2007; J. Z. Sawicki, Bitwa o prawdę. Historia zmagań o pamięć Powstania Warszawskiego. 1944- 1989, Warszawa 2005; R. Stobiecki, Bolszewizm a historia. Próba rekonstrukcji bolszewickiej filozofii dziejów, Łódź 1998; Tenże, Historia pod nadzorem. Spory o nowy model historiografii w Polsce (druga połowa lat czterdziestych - początek lat pięćdziesiątych), Łódź 1993; Tenże, Pierwsza Konferencja Metodologiczna Historyków Polskich, w: Skryte oblicze systemu komunistycznego. Uźródet zła, red. R, Bäcker, P. Hübner, Warszawa 1997; Tenże, Stalinowska wizja dziejów Polski - próba rekonstrukcji modelu, Dzieje Najnowsze, 1993, nr 3, s. 73-82. Kwestii współczesnych stosunków pomiędzy historiografią a polityką i odwrotnie poświęcone było niedawne Forum Historyków Dziejów Najnowszych (10 grudnia 2016, Warszawa). 
się przez ludzi i grupy, narzędziem legitymizacji oraz delegitymizacji różnych postaw i działań, instrumentem oporu, leczeniem nabolałych ciał i umysłów (Aleksander Gieysztor o odbudowie Zamku: „Byle zacząć teraz, a może za rok coś da się udostępnić spragnionym pociechy narodowej”| ${ }^{\prime 4}$. Treści historyczne służyły (służą) leczeniu frustracji i kompleksów (w tym narodowych), podbijaniu „narodowego bębenka”, oddawaniu sprawiedliwości pokrzywdzonym. Bywają alfabetem (kostiumem) dla wyrażania pewnych współczesnych treści. To w wyniku wyboru dokonywanego w materii dziejów każdorazowo decydowano jakie tablice mają dekorować kolumny Grobu Nieznanego Żołnierza, jakie rzeźby i ornamenty pomieścić na Pałacu Kultury i Nauki im. Józefa Stalina, jakie stylizowane na postaci historyczne portrety współczesnych polityków niesie się na marszach KOD-u (24 września 2016 r. ktoś niósł portret Jarosława Kaczyńskiego stylizowanego na Stalina, pojawiały się też stylizacje na Kim Ir-sena itd.). Na spotkaniu działaczy i współpracowników KOR oraz przyjaciół „Gazety Wyborczej” Adam Michnik mówil, że członkowie KOR-u czuli się swego czasu uczestnikami polskiej sztafety do wolności. Po treściach intelektualnych zaserwowano na tym spotkaniu przyjęcie w stylu PRL: zimne nóżki, sałatkę jarzynową, zrazy, placki kartoflane, wino „Sophia”... Nie udało się tylko zdobyć wódki z czerwoną kartką („partyjnej”) - bowiem jej już po prostu nie ma. Toast wzniesiono jednak

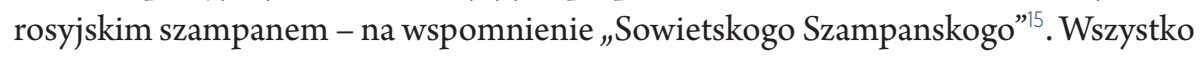
to zaspokajało nie tylko potrzebę zjedzenia placków kartoflanych i wypicia szampana.

Pytanie w jakim stopniu historycy współdziałają w kierunku realizacji społecznych potrzeb związanych z wiedzą o dziejach. Organizatorom wspomnianego spotkania w Gazecie z pewnością nie doradzaliśmy (można tu pominąć, że sam Adam Michnik jest z wykształcenia historykiem, a jeszcze paru historyków też tam pracuje). Podobnie nasi zawodowi koledzy najpewniej nie doradzali malarzom z odmiennego kręgu ideowego, którzy na murze obok kościoła położonego na moim osiedlu wymalowali sceny z Powstania Warszawskiego, mało realistyczne, ale o niewątpliwie patriotycznym wydźwięku (młodzi AK-owcy składają przysięgę, stojąc na baczność, w raczej eleganckich strojach na Krakowskim Przedmieściu, naprzeciwko kościoła św. Krzyża!).

Gdy w Kijowie prezenterka TV wołała „Czy nie możecie ruszyć tyłków i przyjść, żeby pozostać na Majdanie? Za wszystkich przodków, którzy także stali i walczyli o niepodległość i godność nazywania siebie Ukraińcami!” - to żaden historyk jej tego

14 Z listu Aleksandra Gieysztora do Gerarda Labudy, 29 VIII 1980, w: Aleksander Gieysztor, Człowiek i dzieto..., s. 476 .

15 Spotkanie odbyło się 1 października 2016 r. w lokalu Gazety Wyborczej. 
nie podpowiadał, ale ona - choćby nieświadomie - wykorzystywała dorobek naszych ukraińskich pobratymców zawodowych ${ }^{16}$.

O ile na wykorzystywanie tworzonych przez nas treści mamy ograniczony wpływ, to $\mathrm{w}$ zakresie tworzenia treści nie chciałbym zbyt łatwego poddawania się potrzebom ludzi. Wyjąwszy sytuacje wyjątkowe (wojenne, okupacyjne itp.), nie wydaje mi się, ażeby one miały być podstawowym motywem działania historyków. Naszym zadaniem jest - w moim przekonaniu - zwiększanie wiedzy, a nie wychowywanie i socjotechnika. Skądinąd nie widzę, ażeby przełożenie wiedzy nad historyczne książeczki intencjonalnie wychowawcze miało złe skutki. Przekazanie wiedzy jest zawsze cenne. Z uznaniem czytałem ostatnio niektóre książeczki, przekazujące wiedzę historyczną małym dzieciom - jak na przykład tę o zającu, który odwiedza różne epoki i z nich pisze listy do dzieci ${ }^{17}$.

Nie najmniej ważnym tematem dla historii historiografii są wewnętrzne stosunki i nastawienie środowiska historyków, także stopień w jakim te czynniki oddziałują na naszą twórczość. W końcu na ogół musimy zadbać o pensję, zdobywać stopnie naukowe, lubimy być chwaleni i doceniani (to ludzkie!), często obawiamy się zbyt nowych treści i podejść. W stylu naszego pisarstwa jesteśmy bądź bywamy ograniczani przez możliwości wydawnicze, przez cenzurę (niekoniecznie tę sformalizowaną, choć bywa, że i przez taką ${ }^{18}$ ), przez panujące zwyczaje i reguły. Jaki wpływ na naszą twórczość odgrywają rozwiązania instytucjonalne oraz np. kryteria przyjmowania do pracy lub na doktorantury, także kryteria oceny pracowników? W jakim stopniu nasze środowisko i system instytucji popiera ludzi ciekawych, a w jakim przede wszystkim pracowitych? Kogo i z jakich powodów środowisko historyków eliminuje? Pytanie jakie znaczenie odgrywają recenzenci oraz ich recenzje (zarówno te wewnętrzne wydawnicze, a w niektórych okresach wewnętrzne polityczne, jak recenzje w przewodach awansowych, czy drukowane z opublikowanych prac)? Jaką rolę odgrywają mniej czy bardziej brutalne ataki na historyków oraz na ich twórczość - czasem otwarte, a czasem anonimowe? Również takie, w których polityka w pełni miesza się z wizją historii i z oceną ludzi jako takich? Szkoda je cytować, a nawet wymieniać nazwiska atakujących - bowiem trudno jest odpowiadać na nie łagodnie, a przykro ostro.

Fundamentalne dla historiografii jest to, czy pojawiają się wśród nas „przewodnicy stada” i jacy oni są. Jaki wpływ wywierają, jakie są mechanizmy ich oddziaływania?

16 Ogień Majdanu. Dziennik rewolucji. 21.11.2013- 22.02.2014, koncepcja Z. Gluza, wybór i opr. M. Kowalczyk, A. Richter, tłum. M. Kowalczyk, M. Piotrowski, A. Richter, T. Szumejko, Warszawa 2015, s. 32 (słowa W. Arbuzowej-Powell).

17 A. Langen, C. Droop, Nowe listy od Feliksa. Mały zając podróżuje po przeszłości, Warszawa 2010.

18 Cenzura w PRL. Relacje historyków, opr. Z. Romek, Warszawa 2000; Z. Romek, Cenzura a nauka historyczna $w$ Polsce 1944- 1970, Warszawa 2010. 
Przecież to naiwność sądzić, że o kierunku rozwoju nauki przesądzają tylko wybitne umysły. Posiadacz takiego umysłu musi jeszcze mieć odpowiednią siłę przebicia i oddziaływania. O niektórych postaciach można jednak bez wahania powiedzieć, że powinny stać się przedmiotem zainteresowania historii historiografii nie tylko z powodu książek, które stworzyli, jednych z wielu na rynku. Aleksander Gieysztor napisał o Marcelim Handelsmanie, że „zaważył na rozwoju polskiej mediewistyki przez wyprowadzenie jej z opłotków partykularnych; przez wskazywanie jej problemów historii społecznej wspólnych całej Europie średniowiecznej; przez zapewnienie swoim pracom i zamierzeniom kontynuacji - jednego z podstawowych warunków każdego badania naukowego ${ }^{\prime \prime 19}$. Podobnie, jako człowieka, który w ogromnym stopniu oddziałał na kierunek historiografii, można by scharakteryzować samego prof. Gieysztora, nawet jeśli jego podstawowym dziełem stały się nie tyle książki, ile odbudowany Zamek. Inna sprawa, że prof. Gieysztor miał wielki wpływ na wiele książek, bowiem właśnie szeroko inspirował kolegów.

Przyszły historyk historiografii powinien wziąć pod uwagę, że wydawcy książek historycznych na ogół nie lubią wstępów, czy rozdziałów metodologicznych. Powinien to wykryć jako czynnik oddziałujący na wyniki, nie zaś stwierdzać brak zainteresowań metodologicznych w środowisku. Nasz przyszły kolega powinien przypatrzyć się wpływom systemu punktowego na naszą twórczość. Nie powinien wyciągać wniosków o stylu pisarskim historyków przed wzięciem pod uwagę działań adiustatorek, które na ogół są chore jeśli nie pozmieniają tekstu, który do nich trafia. Rozważania nad stylem pisarskim historyków w ogóle nie będą miały w przyszłości sensu - właśnie $\mathrm{z}$ tego powodu.

Na zakończenie pozwolę sobie wrócić do początku moich wywodów: wiem, że nie jestem specjalistą - historykiem historiografii. Może wszystko powyższe jest odkrywaniem „Ameryki pod poduszką”. Może też, formułując rożne życzenia, zdradzam się niewiedzą o Waszych, Koleżanki i Koledzy, dokonaniach. Jeśli by tak było, to wybaczcie. No i pomóżcie w podniesieniu mojej wiedzy. Pomożecie?

19 Cyt. za: M. Koczerska, Aleksander Gieysztor jako nauczyciel akademicki, w: Aleksander Gieysztor. Człowiek idzieto..., s. 54 . 